\title{
Influence of Anodic Gas Mixture Composition on Solid Oxide Fuel Cell Performance: Part 2
}

\author{
N. Murgi, G. De Lorenzo, O. Corigliano, F. A. Mirandola and P. Fragiacomo * \\ Department of Mechanical, Energy and Management Engineering - University of Calabria \\ Arcavacata di Rende, 87036 Cosenza, Italy \\ Email: petronilla.fragiacomo@unical.it
}

\begin{abstract}
Solid oxide fuel cells are very promising devices for clean energy. Their goodness is amplified by fuel flexibility opening the possibility of fuelling with alternative and clean fuels such as syngas, deriving from biomass conversion treatments.

This paper follows a first paper (Part 1) where analysis in terms of fuel composition, specifically in terms of $\mathrm{CO} / \mathrm{H}_{2}$ ratio, were carried out, mainly to outline the field that enables a secure functioning far from carbon deposition. In this paper (Part 2) a careful analysis of SOFCs performance for varying concentrations of the gas components of a generic stream of syngas $\left(\mathrm{H}_{2}, \mathrm{CO}, \mathrm{N}_{2}, \mathrm{CO}_{2}, \mathrm{H}_{2} \mathrm{O}\right)$ and operating conditions (pressure, temperature, flow rate of the gas-mixture), was performed in order to plan the actual test campaigns.

The effects the significant parameters have on fuel cell performance will then be exhibited by the analysis of the planned testing campaigns to be performed on a generic laboratory prototype.
\end{abstract}

Keywords: SOFC, Syngas, Hydrogen, Clean energy, Testing planning.

\section{INTRODUCTION}

Current issues such as the gradual exhaustion of fossil fuel reserves and the simultaneous increase in global energy demand, high oil prices, pollution and climate change of the planet have now been for several years at the center of national and international debates [1].

Solid oxide fuel cells (SOFC) are considered one of the most promising energy conversion devices and a good alternative to existing power generation systems. An advantage of SOFCs is that they can be fed not only by conventional fuels (methane or hydrogen), but also by nonconventional fuels such as syngas, i.e. the gas produced by coal or woody biomass gasification, which is mainly composed of carbon monoxide $(\mathrm{CO})$, hydrogen $\left(\mathrm{H}_{2}\right)$ and carbon dioxide $\left(\mathrm{CO}_{2}\right)[2,3,4]$.

The present paper (Part 2) proceeds to discuss the significant aspects that characterize the SOFC when syngas fuelled.

The previous paper (Part 1) reports the analysis of performances mainly focused on syngas composition. In particular, special attention is dedicated to safe functioning by monitoring possible carbon deposition. Part 1 is therefore focused on finding the region of fuel composition (mainly in terms of $\mathrm{CO}$ content) and regime conditions (pressure and temperature) that assures secure functioning for an SOFC laboratory prototype [5].
This paper (Part 2) analyzes the influences of the operating conditions (pressure, temperature, flow rate of the mixture), on the behavior of the SOFC, and considers and compares different case studies (a [6], b [7], c [8], d [10]), (case study a and $b$ are mainly discussed in the first paper, Part 1 ).

The effects the significant parameters have on the performance of the cell will then be exhibited, from subsequent analysis testing campaigns will be planned to be performed for a laboratory prototype.

\section{TEMPERATURE EFFECT}

To assess this effect we will consider, first, the experimental analysis performed by Lia et al. (case study c) [8], designed to determine the influence of syngas from biomass on the performance of a tubular SOFC (anode: NiYSZ) with a respectively volume fraction of $\mathrm{H}_{2}, \mathrm{CO}, \mathrm{CH}_{4}$, $\mathrm{CO}_{2}$ of: $42 \%, 1 \%, 13 \%, 44 \%$. Then we will compare the different case studies analyzed.

\subsection{Anodic polarization}

A first study is performed by analyzing the impedance spectra at open circuit voltage, at $800^{\circ} \mathrm{C}$ (a) and $900^{\circ} \mathrm{C}$ (b), in the case of feeding syngas or hydrogen.

The impedance spectra were measured in the same conditions, then the difference in the value of Rp (or Rct) 
was derived from the difference in the composition of the fuel gas, as reported by Aloui et al. [9].

The experimental tests showed no concentration polarization even for current density higher than $1.6 \mathrm{~A} / \mathrm{cm}^{2}$, indicating that the porosity of the anode allows a great diffusion of the reactant gas.

Studies conducted by Aloui [9] have also demonstrated that anodic activation has a tendency to be higher than cathodic activation. Therefore, $\mathrm{Rp}$ is essentially the anodic activation polarization.

By analyzing the impedance spectra, it can be concluded that the difference of anodic polarization ( $\mathrm{Rp}, \mathrm{S}-\mathrm{Rp}, \mathrm{H}_{2}$ ) decreases with increasing temperature, from approximately 0.8 to $0.23 \Omega \mathrm{cm}^{2}$, when the operating temperature increases from $800^{\circ} \mathrm{C}$ to $900^{\circ} \mathrm{C}$. This reduction is due to the high catalytic activity of the anode at high temperatures.

High temperatures therefore reduce the gap in performance between $\mathrm{H}_{2}$ and syngas.

\subsection{Fuel cell performance}

The current density equation, reported in (1) is opportune for the comprehension of the fuel cell electrical parameters.

$\mathrm{i}=\mathrm{nF}\left(\frac{\mathrm{df}}{\mathrm{dt}}\right)_{\text {cons }}$

Hence it is easy to understand that an increase in cell current is directly proportional to the amount of fuel consumed. In the equation ' $n$ ' is the number of electrons involved in the electrochemical reaction, ' $F$ ' is the Faraday constant and $(\mathrm{df} / \mathrm{dt})_{\text {cons }}$ is the molar flow rate of fuel consumed. The increase in the fuel cell voltage ' $\mathrm{V}$ ' is proportional to the increase of the reactants concentration. Power density ' $\mathrm{dP}$ ' is the product $\mathrm{V} \cdot \mathrm{i}$. The influence of temperature on an anode supported tubular SOFC single cell with different fuel compositions at $800^{\circ} \mathrm{C}$ and $900^{\circ} \mathrm{C}$ is evaluated. Figure 1 (a) reports the analysis as a function of the temperature on the cell performances, based on the processing of the data collected in [8], The fuel feeding is represented by pure hydrogen and syngas. As expected, it can be stated that increases in the operating temperature of the cell imply improvement in the SOFC performances. The main reason is that the electrical conductivity of the electrolyte increases with increase in temperature; moreover, the electrode polarization is reduced. It can be found that the cell voltage decreased almost linearly with the increase of output current density, independently of the feeding. This means that, with the test cells used in the work [8], although the anodic activation using syngas is higher, the Ohmic polarization is mainly responsible for the reduction of cell voltage. It can also be found that the concentration polarization is not significant even when the current density is greater than $0.8 \mathrm{~A} / \mathrm{cm}^{2}$. However, the activation polarization can be observed at the current density lower than $0.12 \mathrm{~A} / \mathrm{cm}^{2}$ using syngas fuel at the temperature of $800^{\circ} \mathrm{C}$. This is mainly because the anodic activation using syngas is about twice as high as when using hydrogen.
The maximum output power density using hydrogen as fuel is $0.45 \mathrm{~W} / \mathrm{cm}^{2}$ at $900^{\circ} \mathrm{C}$. However, the maximum output power density using syngas as fuel decreases by about $27 \%$ to $0.33 \mathrm{~W} / \mathrm{cm}^{2}$. The maximum output power density decreases by about $34 \%$ as the fuel changes from hydrogen to syngas when the temperature is reduced to $800^{\circ} \mathrm{C}$.

\subsection{Case studies comparison}

Table 1 shows the data of the various case studies analyzed, in order to accomplish an opportune evaluation and a wide mapping of SOFC behavior when syngas powered.

As known, the increase in performance is evident when increasing operating temperature.

The comparison is performed on the data extracted from [3, $5,7]$. In the paper [10] the fuel composition is $39.58 \%$ of $\mathrm{CO}$, $30.28 \%$ of $\mathrm{H}_{2}, 10.78 \%$ of $\mathrm{CO}_{2}, 16.45 \%$ of $\mathrm{H}_{2} \mathrm{O}, 0.079 \%$ of $\mathrm{CH}_{4}, 2.12 \%$ of $\mathrm{N}_{2}$ (case study d). As can be observed, at very low current density the cell performances have all quite similar values. Clearer differences are revealed at higher current densities.

However, performances have a quite opposite behavior with relatively high $\mathrm{CO}_{2}$. Indeed, although difficult to detect in this range of data collection, more specific detection and comparisons made on the same fuel feeding show that an increase in temperature, particularly at very low current density, results in a reduction of the cell voltage. A first reason has to be attributed to Nernst Voltage which has an inversely proportional behavior with temperature, a second effect can be attributed to reverse WGS reaction, which due to the high concentration of $\mathrm{CO}_{2}$ and due to its endothermic nature, uses heat and therefore high temperatures to shift the equilibrium toward the reactants, thus producing $\mathrm{CO}$ and $\mathrm{H}_{2} \mathrm{O}$, and reducing the amount of $\mathrm{H}_{2}$.

Anyway, a higher temperature allows the formation of carbon to be reduced and prevented.

Table 1. Comparison among case studies

\begin{tabular}{lllll}
\hline & $\mathrm{T}: 800{ }^{\circ} \mathrm{C}$ & $\mathrm{T}: 900{ }^{\circ} \mathrm{C}$ \\
\hline & $\mathrm{i}\left[\mathrm{A} / \mathrm{cm}^{2}\right]$ & $\mathrm{V}[\mathrm{V}]$ & $\mathrm{i}\left[\mathrm{A} / \mathrm{cm}^{2}\right]$ & $\mathrm{V}[\mathrm{V}]$ \\
\hline $\begin{array}{l}\text { Syngas } \\
\text { (variable } \mathrm{H}_{2} / \mathrm{CO}\end{array}$ & 0 & 1.1 & 0 & 1.2 \\
@ $\left.\mathrm{N}_{2}: 70 \%\right)[6]$ & 0.1 & 0.65 & 0.1 & 0.75 \\
\hline Mix @ variable & 0 & $1.0-1.05$ & 0 & $1.1-1.2$ \\
$\mathrm{H}_{2} / \mathrm{N}_{2}$ [6] & 0.1 & $0.6-0.8$ & 0.1 & $0.7-0.9$ \\
\hline $\mathrm{H}_{2}[8]$ & 0 & 1.05 & 0 & 1.04 \\
\hline \multirow{2}{*}{ Syngas [8] } & 0.1 & 0.9 & 0.1 & 0.95 \\
\hline $\mathrm{Mix}_{\mathrm{H}}$ @ variable & 0 & 1.01 & 0 & 1.0 \\
$\mathrm{H}_{2} \mathrm{CO}_{2}[6]$ & 0.1 & 0.86 & 0.1 & 0.935 \\
\hline
\end{tabular}


(a)

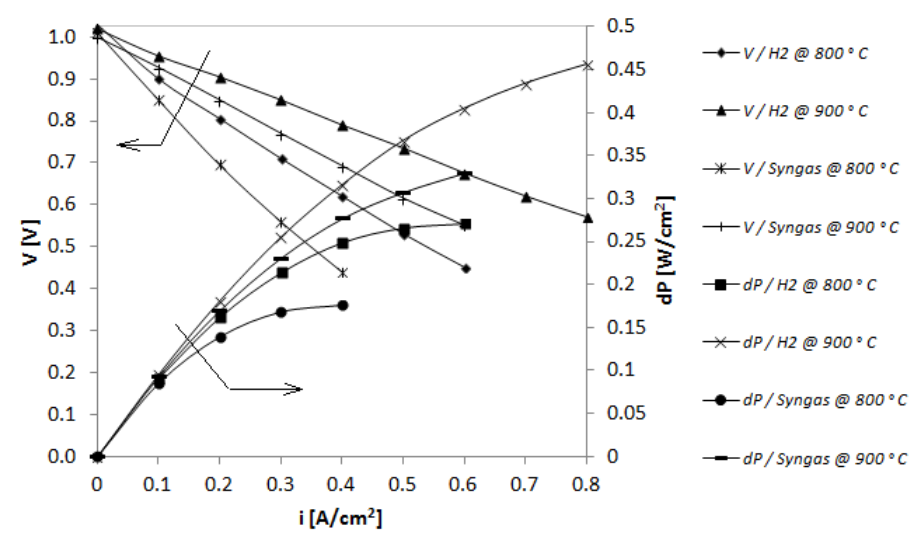

(c)

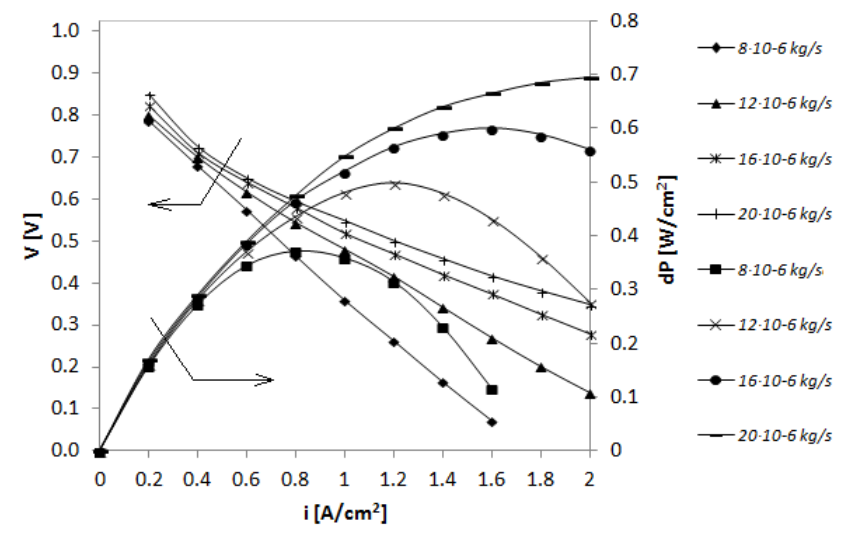

(b)

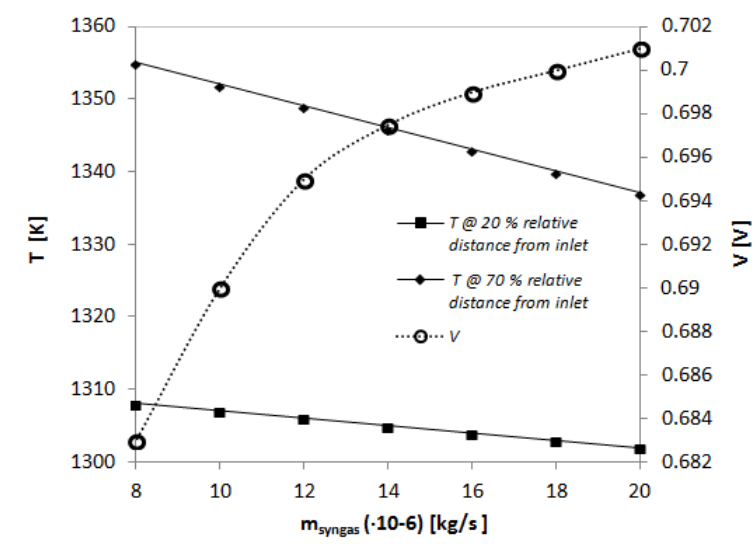

(d)

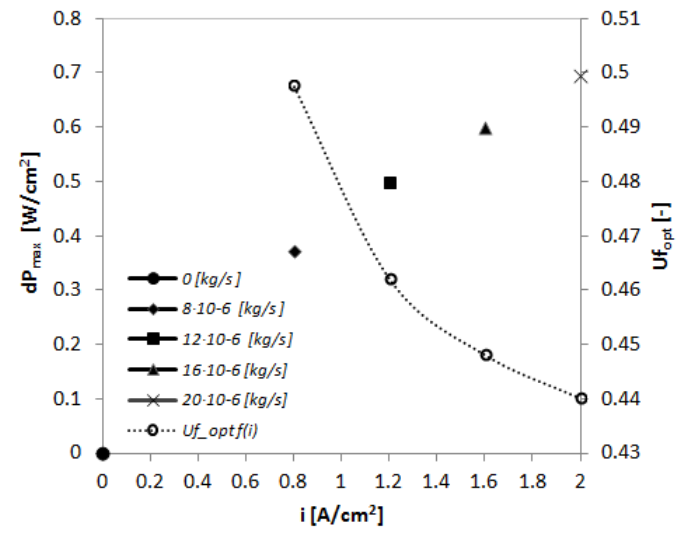

Figure 1. (a) Solid Oxide Performances, $\mathrm{i}-\mathrm{V}$ and i-dP curves for hydrogen and syngas feeding, temperature and voltage curves as a function of syngas flowrate at $1000{ }^{\circ} \mathrm{C}(\mathrm{b}), \mathrm{i}-\mathrm{V}$ and i-dP curves for various syngas flowrates at $1000{ }^{\circ} \mathrm{C}$ (c), maximum power density curve and fuel utilization factor vs. current density at $1000{ }^{\circ} \mathrm{C}$ (d)

\section{EFFECT OF THE FLOW RATE OF SYNGAS}

To assess this effect we will consider the work carried out in [10]. Its aim is to determine the favorable operating conditions of a planar SOFC (anode: Ni-YSZ) operating at about $1000^{\circ} \mathrm{C}$ by feeding different flow rates of syngas (case study d).

Most of the following paragraphs are dedicated to commenting on Figure 1, where each of them analyses the influence of a single parameter on performances.

\subsection{Temperature and voltage distribution}

Figure 1 (b) reports the temperature distribution, and the cell voltage vs. the dimension of the flow direction. The first case considers the effect of syngas flow rate on the distribution of temperature and of voltage in the cell electrolyte at an average current density of $0.4 \mathrm{~A} / \mathrm{cm}^{2}$. In SOFC cell, heat is mainly released by electrochemical reaction. When the current density through electrolyte is constant, the total heat released from electrochemical reaction is constant as well. The heat taken away by fuel in the anode increases with the increase of syngas flow rate. Therefore, the temperature in the SOFC cell is reduced. In particular, the data related to the temperature records at $20 \%$ and $70 \%$ of distance from inlet are collected, which are representative respectively of values close to minimum and maximum. Between the two zones, as can be observed, a difference of more than $40{ }^{\circ} \mathrm{C}$ is evident, meaning that the zones close to the inlet are fresher than those close to the outlet. This is clear since more gas reacts to generate electricity. By the analysis of the overall data, the outlet station shows a lightly lower temperature than the station at $70 \%$ of distance from inlet. This is due to the amount of depleted fuel that increases and acts as a diluter and as a heat extractor.

Furthermore, it can be found that the temperature difference, between maximum and minimum, at fixed distance from the inlet, decreases with the increase of syngas flow rate. The smaller temperature difference is beneficial for reducing the thermal stress in the SOFC and is helpful to the sealing of SOFC stacks. Under the calculating conditions, the temperature differences in the electrolyte at the relative distances from inlet equal to $20 \%$ and $70 \%$ are respectively reduced by about $10 \mathrm{~K}$ and about $3 \mathrm{~K}$ with each $6 \cdot 10^{-6} \mathrm{~kg} / \mathrm{s}$ rise of syngas flow rate. Moreover, the change of temperature difference with the increase of syngas flow rate is nearly linear.

With regard to cell voltage, the results show that the increase of syngas flow rate is beneficial to increasing the output voltage, but its effect is gradually weakened with the increase of syngas flow rate. This reason may be that higher 
concentration of $\mathrm{CO}$ and $\mathrm{H}_{2}$ at larger flow rate of syngas makes the concentration over-potential lower. But the overpotential of ohm and activation increases because the temperature in the electrolyte and the anode is lower. On the whole, the increase of syngas flow rate is beneficial to enhancing the output voltage even by $0.018 \mathrm{~V}$.

\subsection{Species distribution}

The change of molar fraction of species is studied as the difference of the mole fraction of species between output and input, with the variation of syngas flow rate [10]. With the increase of syngas flow rate, the molar fractions of hydrogen and carbon monoxide increase and those of steam and carbon dioxide decrease as well. These changes are nonlinear with the increase of fuel flow rate, this is to say that the electrochemical reaction is not uniform along the length direction of the cell. In addition, this also indicates that the fuel utilization decreases as the increase of syngas flow rate at the constant average current density.

\subsection{Output voltage and power density}

The output voltage trend is also studied at a constant average current of $0.4 \mathrm{~A} / \mathrm{cm}^{2}$, by varying the flow of syngas.

In order to fully understand the optimal performance of SOFC cell at different flow rate of syngas, voltage and power density at different current density are analyzed. The analysis is reported in Figure 1 (c). With the increase of syngas flow rate, the range of average current density at which the SOFC cell has power output is enlarged, and the optimal power density is enhanced as well. Under these working condition, when the syngas flow rate increases from $8 \cdot 10^{-6} \mathrm{~kg} / \mathrm{s}$ to $20 \cdot 10^{-6} \mathrm{~kg} / \mathrm{s}$, the optimal power density is enhanced by $85 \%$ and the current density that accomplish the maximum power density increases by $117 \%$.

\subsection{Maximum power densities and fuel utilization analysis}

The present analysis is reported in Figure 1 (d). In particular, it interpolates the maximum values of power densities that are produced and reports the values of the "optimum" fuel utilization factors that are calculated for the aforementioned power densities.

The maximum power densities line presents a parabolic profile, meaning that its growing can not be linear with the increase of syngas flow rate, but, on the contrary, it tends to reach a maximum value that encounters in as asymptotic manner (given the numerical field of evaluation, probably the aforementioned trend is parabolic, with a peak and then starts to decrease). This is probably due to the cooling effect of the gas that at high flow rates begins to be significant, in addition to the diffusion phenomena effects.

As for the fuel utilization factor, with the increase of fuel flow rate, it decreases as the current decreases, matching the optimal output power density. This effect is closely related to the diffusion phenomena at the anode; increasing the feed flow rate, the diffusion rate in the porous electrode limits the consumption of the gas, reducing the current deliverable.

When the syngas flow rate is $8 \cdot 10^{-6} \mathrm{~kg} / \mathrm{s}$, the fuel utilization is about $50 \%$. However, when the syngas flow rate increases to $20 \cdot 10^{-6} \mathrm{~kg} / \mathrm{s}$, the fuel utilization reduces to $43 \%$. Therefore, its trend tend to decrease when searching the maximum power density.

\section{ENERGY ANALYSIS}

The present energy analysis is aimed at assessing the electrical efficiency of the solid oxide fuel cells. The study reports the analysis by processing the data of $[5,7]$, when feeding with hydrogen and syngas.

Figure 2 (a) reports the electrical efficiency for hydrogen feeding when SOFC is operated at 800 and $900^{\circ} \mathrm{C}$. As can be observed, there is a quite wide difference between the two regimes. An increase in temperature of $100{ }^{\circ} \mathrm{C}$ implies an increase in the maximum electrical efficiency of about $20 \%$, by moving the value from 0.3 (at $0.6 \mathrm{~A} / \mathrm{cm}^{2}$ ) to 0.5 (at 0.8 $\mathrm{A} / \mathrm{cm}^{2}$ ). This is due to reduction of ohmic polarization that causes a minor slope in the $\mathrm{i}-\mathrm{V}$ curve, and a shift to much higher current density, which is the proof of the diffusion phenomena that subsequently cause performance degradation.

Figure 2 (b) reports the electrical efficiency for a syngas feeding when SOFC is operated at $1000{ }^{\circ} \mathrm{C}$, for different syngas flow rates. The figure clearly shows how the maximum values of electrical efficiency diminish when the syngas flow rate increases, exactly the contrary of what happened and can be noticed in Figure 1 (c). These peaks are recorded at increasing values of current density.

This effect is caused by the large amount of gas that remains undepleted, thus enlarging the potential chemical power of the primary gas, most of which is unreacted. On the other hand, the decrease in efficiency is due to the reduction of the fuel utilization factor with the flow rate. This effect is closely related to the diffusion phenomena at the anode, which restrict the consumption of the gas with increasing the flow rate in the feed. In essence, with the increase in flow rate, the amount of fuel consumed and then the output power is greater, but the ratio of the gas reacted to that in feeding decreases, leading to a decrease in efficiency.

Each efficiency profile has a parabolic trend that tends to enlarge its concavity, when flow rates increases. One more aspect that can be presented is that interpolating the various peaks, they generate a parabolic profile with a soft slope vs. current density. The maximum electrical efficiency is about 0.45 .

\section{CONCLUSIONS}

On the basis of the assessments made and presented in both papers (Part 1 and Part 2), a planning of tests and campaigns for a laboratory SOFC prototype can now be listed. This plan is aimed at carrying out and assessing the prototype performance in terms of electrical efficiency, at varying the considerable parameters.

Therefore we can now define the range of changes that will be imposed on significant parameters, on which an experimental testing campaign will be based. 
(a)

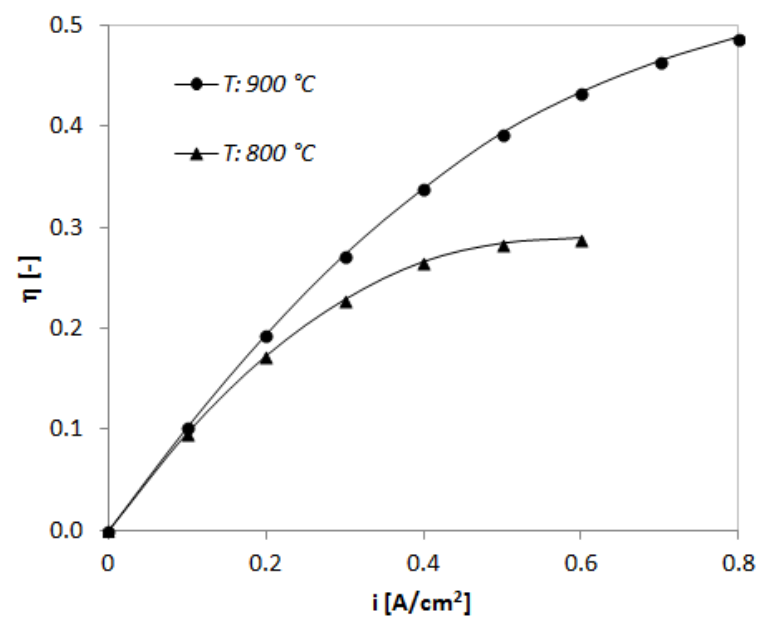

(b)

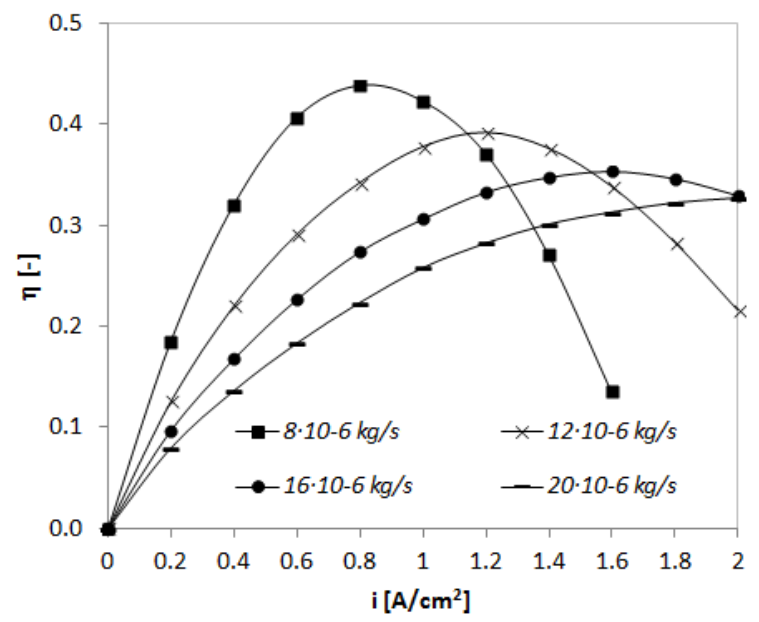

Figure 2. Electrical efficiency vs. current density, for pure hydrogen feeding (a), syngas feeding (b)

\section{- Temperature}

Given the present and prospective tendencies of operating with Low/Intermediate Temperature SOFC, it is opportune to operate the device at about $700{ }^{\circ} \mathrm{C}$.

\section{$-\mathrm{CO} / \mathrm{H}_{2}$}

For various analyses, the focus is on the $\mathrm{CO} / \mathrm{H}_{2}$ ratio. It can be varied in ascending order in the range $0 / 100$ to $40 / 60$, at least in the first phase, with the possibility of moving to $60 / 40$ in the second phase. For the aforementioned ratios, it is very important to fix the maximum composition of $\mathrm{CO}$ better, which must not exceed $25 \%$. Then, a significant percentage of nitrogen can be adopted to ensure a diluent effect in order to further reduce the danger of carbon deposition. Experimental tests can be carried out in an operating temperature range that is typical of a laboratory oven for an Intermediate SOFC Temperature, e.g. $650-750$ ${ }^{\circ} \mathrm{C}$.

The choice of limiting this high $\mathrm{CO} / \mathrm{H}_{2}$ ratio, e.g. $40 / 60$ is linked essentially to two factors:

[1] the $\mathrm{CO} / \mathrm{H}_{2}$ ratio that provides the best performance is in the range $20 / 80-30 / 70$, as noticed above;

[2] there is a need to preserve the integrity of the stack, to ensure proper operation, thus preventing carbon deposition, for as long as possible a period of time.

\section{$-\mathrm{N}_{2}$}

The tests will be performed starting from a concentration of $\mathrm{N}_{2}$ of $90 \%$, reducing it step by step until reaching the complete absence of $\mathrm{N}_{2}$. Although the concentration of $\mathrm{N}_{2}$ of $90 \%$ is so high as to lead to a significant drop in performance, we can however investigate the behavior of our stack in such conditions, because the nitrogen poses no danger of deterioration of the system. The tests can be performed in the entire operating temperature range.

This may be performed either with a mixture of only $\mathrm{H}_{2}$ and $\mathrm{N}_{2}$, for the ratios of $\mathrm{CO} / \mathrm{H}_{2}$ that guarantee the best performance, i.e. fixing these ratios and varying the concentration of $\mathrm{N}_{2}$.
The main interest is to determine the range of powers, and hence current density, in which the dilution has no particular effect on performance.

\section{$-\mathrm{CO}_{2}$}

The addition of $\mathrm{CO}_{2}$ in the fuel mixture mostly connotes the fuel as syngas. Hence, apart from considering a precise composition, the amount of $\mathrm{CO}_{2}$ can be adopted both to detect cell performance by varying the same $\mathrm{CO}_{2}$, which acts as a diluents, and to prevent carbon deposition. As observed, $\mathrm{CO}_{2}$ is the most favorable diluent to monitor and prevent carbon formation.

\section{$-\mathrm{H}_{2} \mathrm{O}$}

The concentration of $\mathrm{H}_{2} \mathrm{O}$ can be varied in the range of $0 \div 20 \%$ to consider and assess its effect on performances.

The use of $\mathrm{H}_{2} \mathrm{O}$ also limits the deposition of carbon but at the same time reduces the power delivered. A negative effect could derive from its excessive presence. A high amount of $\mathrm{H}_{2} \mathrm{O}$ increases the risk of sintering of the nickel anode. For these reasons, a possible prolonged operation of the stack with the concentration of $\mathrm{H}_{2} \mathrm{O}$ higher than $20-25 \%$ is opportune only for low temperatures, expressly to prevent carbon deposition.

\section{-Simulated syngas}

Once separately assessed the effects of $\mathrm{CO} / \mathrm{H}_{2}$ and the dilution of $\mathrm{N}_{2}, \mathrm{CO}_{2}$ and $\mathrm{H}_{2} \mathrm{O}$, and determined the conditions that offer the best performance, it is necessary to identify mixtures of syngas that ensure the more advantageous benefits.

- $\dot{\mathbf{m}}_{\text {syngas }}$

Choosing the composition of the entering simulated syngas that provides the more interesting performance, the flow rate will be increased until no significant changes of the output power from the stack will be detected. Therefore, the efficiency and capacity utilization to varying the flow rate will be evaluated. 
The minimum flow rate of the $\mathrm{H}_{2}$ to ensure proper wettability of the anode is $0.9 \mathrm{Nl} / \mathrm{min}$. The tests will be carried out in the entire operating temperature range.

Once carried out these experimental tests and identified the conditions and compositions that provide the most interesting performances, the tests will be performed for long periods of time in which repeatability can also be verified. Therefore it will be evaluated whether mixtures that offer the best performance are also suitable for continuous operation or whether they will lead to the deterioration of cells, and then a drop in performance.

Given the nature of the materials of the cells that constitute a typical stack, the best performance, both in terms of electrical performance and abatement of carbon deposition, will be obtained at the maximum temperature.

As regards the composition of the mixture feeding, which will give the best results, based on the analysis performed, it will presumably have the following characteristics:

$-\mathrm{CO} / \mathrm{H}_{2}$ ratio of about $20 / 80$ to $35 / 65$, although considering the carbon monoxide as fuel, thereby contributing to electricity generation, but its rate of oxidation is lower than that of hydrogen thus limiting the performance especially at high current density. Moreover, a higher concentration generates carbon deposition;

$-\mathrm{N}_{2}$ concentration of $30-40 \%$ : is able to ensure an appropriate dilution effect, mainly on $\mathrm{CO}$, necessary to prevent the possible deposition of carbon, while still providing a fairly contained drop in performance.

- $\mathrm{H}_{2} \mathrm{O}$ concentration of $3 \%$ is considered to be the minimum value to be observed to keep the cell wettability. Actually, case by case, the minimum value is to be simulated and acted on in order to prevent carbon formation.

Although all the parameters considered have a significant effect on the performance of SOFC, the factor of greatest interest on which to focus research is the $\mathrm{CO} / \mathrm{H}_{2}$ ratio. This factor must be assessed scrupulously since it affects the useful life of the cells, as the accumulation of carbon deactivates the reaction surface definitively.

\section{REFERENCES}

[1] A. Mirandola, E. Lorenzini, "Energy, environment and climate: From the past to the future," Internatiomal Journal of Heat and Technology, vol. 34, no. 2, pp. 159-164, 2016. DOI: 10.18280/ijht.340201

[2] G. De Lorenzo and P. Fragiacomo, "Energy analysis of an SOFC system fed by syngas," Energ. Convers. Manage. vol. 93, pp. 175-186, 2015. DOI: 10.1016/j.enconman.2014.12.086.

[3] O. Corigliano and P. Fragiacomo, "Technical analysis of hydrogen-rich stream generation through $\mathrm{CO}_{2}$ reforming of biogas by using numerical modeling," Fuel, vol. 158, pp. 538-548, 2015. DOI: 10.1016/j.fuel.2015.05.063.

[4] Mejri, A. Mahmoudi, M. A. Abbassi, A. Omri, "LBM simulation of heat transfer in solid oxide fuel cell," Internatiomal Journal of Heat and Technology, vol. 34, no. 3, pp. 351-356, 2016. DOI: 10.18280/ijht.340301.
[5] N. Murgi, G. De Lorenzo, O. Corigliano, F. A. Mirandola and P. Fragiacomo, "Influence of Anodic Gas mixture composition on solid oxide fuel cell performance: Part 1," Internatiomal Journal of Heat and Technology, vol. 34, Special Issue 2, 2016.

[6] R. Suwanwarangkul, E. Croiset,, E. Entchev, S. Charojrochkul, M. D. Pritzker, M. W. Fowler, P. L. Douglas, S. Chewathanakup and H. Mahaudom, "Experimental and modeling study of solid oxide fuel cell operating with syngas fuel," J. Power Sources, vol. 161, pp. 308-322, 2006. DOI: 10.1016/j.jpowsour.2006.03.080.

[7] Julie S. O'Brien and Javier B. Giorgi, "Solid oxide fuel cell with NiCo-YSZ cermet anode for oxidation of $\mathrm{CO} / \mathrm{H}_{2}$ fuel mixtures," J. Power Sources, vol. 200, pp. 14-20, 2012. DOI: 10.1016/j.jpowsour.2011.10.080.

[8] C-X. Li, C-J. Li and L-J. Guo, "Performance of a $\mathrm{Ni} / \mathrm{Al}_{2} \mathrm{O}_{3}$ cermet-supported tubular solid oxide fuel cell operating with biomass-based syngas through supercritical water," Int. J. Hydrogen Energ., vol. 35, pp. 2904-2908, 2010. DOI: 10.1016/j.ijhydene.2009.05.033.

[9] T. Aloui and K. Halouani, "Analytical modeling of polarizations in a solid oxide fuel cell using biomass syngas product as fuel," Appl. Therm. Eng., vol. 27, pp. 731-737, 2007.2 DOI: 10.1016/j.applthermaleng.2006.10.011.

[10] Y. Wang, J. Yu and X. Cao, "Numerical analysis of optimal performance of planar electrode supported solid oxide fuel cell at various syngas flow rates," Energ. Convers. Manage., vol. 77, pp. 637-642, 2014. DOI: $10.1016 /$ j.enconman.2013.10.020.

\section{NOMENCLATURE}

$\begin{array}{ll}\text { WGS } & \text { Water Gas Shift reaction } \\ \text { rWGS } & \text { Reverse Water Gas Shift reaction } \\ \text { Mix } & \text { mixture } \\ \mathrm{i} & \text { current density, } \mathrm{A} / \mathrm{cm}^{2} \\ \mathrm{~V} & \text { voltage, } \mathrm{V} \\ \mathrm{dP} & \text { power density, W/cm }{ }^{2} \\ \mathrm{YSZ} & \text { Yttria-Stabilized Zirconia } \\ \mathrm{p} & \text { pressure, atm } \\ \mathrm{T} & \text { temperature, }{ }^{\circ} \mathrm{C} \text { or } \mathrm{K} \\ \mathrm{f} & \text { molar fraction } \\ \mathrm{m} & \text { mass flow rate, } \mathrm{kg} / \mathrm{sec} \\ \mathrm{U}_{\mathrm{f}} & \text { fuel utilization factor } \\ \mathrm{F} & \text { Faraday constant }, \mathrm{C} / \mathrm{mol}\end{array}$

Greek symbols

$\alpha$

$\eta$

carbon deposition parameter

Electrical efficiency

\section{Subscripts \\ $\max \quad$ maximum \\ opt optimum}

